\title{
FREQUENCY OF DISEASES PRESENTING IN ENT OPD AT AYUB TEACHING HOSPITAL ABBOTTABAD
}

\author{
Qayyum Fahad Shah, ${ }^{1}$ Fayyaz Salma ${ }^{2}$ \\ ${ }^{1}$ Ayub Medical College, Abbottabad, Pakistan \\ 2 Al-Muslim Public School Battagram, Mansehra, Pakistan
}

Primljen/Received 30. 01. 2019. god.

Abstract: Introduction: Patient presents with ear, nose and throat diseases in ENT OPD to otolaryngologist/ENT specialist. ENT diseases are serious public health problems because of their universal distribution the morbidities which they cause due to inherent physiological function that take place in head and neck region. Objectives of our study were to know frequency of ENT diseases in patients presenting at ENT OPD at Ayub Teaching Hospital Abbottabad.

Methods: A cross sectional study was done in Ayub Teaching Hospital Abbottabad from December 2015. to August 2016. Patients presenting at ENT OPD of Ayub Teaching Hospital Abbottabad were selected for study. Data about their ENT problems and concerned information were collected from them through well structured questionnaire. Data after collection was entered and analysed using SPSS-16.

Results: The minimum age is 1 and maximum age is 80 years. Out of total 250 patients, $129(51.6 \%)$ were males and 121 (48.4\%) were females, majority of patients $181(72.4 \%)$ were from Abbottabad and majority of patients $165(66.0 \%)$ were poor. The most common cases in ENT OPD were bilateral ear wax 15.2\% followed by acute otitis media $13.2 \%$ and allergic rhinitis $13.2 \%$.

Conclusion: It is concluded from our research that most common problems of ENT disorders are bilateral ear wax, allergic rhinitis, acute otitis media, chronic supporative otitis media and deviated nasal septum. The most common causes are infection, poor hygiene and poor nutrition.

Key words: Frequency, ENT diseases, Otitis media, ENT OPD patients of Ayub Teaching Hospital, Abbottabad.

\section{INTRODUCTION}

Patient presents with ear, nose and throat diseases in ENT OPDto otolaryngologist/ ENT specialist (1). The pattern of ENT diseases is quiet variable depend-
Prihvaćen/Accepted 06. 06. 2019. god.

ing on age and group varying from community to community. They may be congenital or acquired in origin. Acquired diseases may be infectious, inflammatory, neurological and vascular or they may be due to some trauma. Complications occur in hearing, breathing, phonation, swallowing, speech, olfaction, taste and protection of lower respiratory tract (2).

In ENT OPD the most presenting ear diseases are ear infection, conductive hearing loss, otitis externa and chronic otitis media (3). The otitis media is the most common disease in young patient because of its more horizontal orientation in children than adults (4). In a survey done by WHO chronic suppurative otitis media (CSOM) was reported to be the most common cause of hearing loss in children in developing countries. Survey on prevalence of CSOM have shown the global burden of illness from CSOM involves 65-330 million individuals $60 \%$ of whom suffer from significant defect (5). In ear diseases oral medication response is excellent while surgical intervention is less frequently required (6).

Diseases of nose which presents the ENT OPD are nasal deformities, tumours, disease of nasal vestibule, nasal septum deviation, nasal polyps, rhinitis, epistaxis, etc. Causes of nasal diseases are trauma, nose surgery and infections. Complication that occurs due to nasal diseases are meningitis, cavernous sinus thrombosis and septal abscess (7). Acommon problem of nose affecting 60 million Africans each year is epistaxis. Most of its cases are minor and manageable but some presents as a life threatening problem. Common local causes are trauma, anatomical deformities and tumours. Cardiovascular diseases and hypertension are its systemic causes (8). Epistaxis is a common problem in children in Kiesselbach area due to local irritation in children (9). Epistaxis is initially treated by first aid measures but other times need some special measures to treat (10). 
Most common throat diseases in outdoor patient department are sore throat, tonsillitis, pharyngitis and cancers. Causes of throat disease are usually a viral infection but other causes include allergies. Complication of throat diseases is acute rheumatic fever; acute glomerular nephritis and peritonsillar abscess formation (11). Second most common cancer of the respiratory tract is the laryngeal cancer. Risk factor for this type of cancer is cigarette smoking, alcohol consumption and may be human papilloma virus 16 and helicobacter pylori (12). Incidence of multiple primary tumours in head and neck region ranges from 10-35 percent (13).

In head and neck malignancies laryngeal cancer accounts approximately for $20 \%$ of all cases. Treatment for laryngeal include total laryngectomy (Tl), alone or with neck dissection (ND), radiotherapy alone (RT), TL followed by RT and combined chemotherapy (14).

Children going to schools are more prone to ENT diseases because of cross infections. This chronic problem not only hampers developmental progress and school performance but also cause physical and emotional suffering (15). Foreign bodies in ear usually found in children below age of ten years it may be iatrogenic or accidental. Tracheobronchial foreign bodies are the major cause of mortality and morbidity in paediatric age group (16).

It has been concluded from a study carried out in India that smoking is the main cause of middle ear diseases in children and adults.Among adults hearing loss is more common with smoking (17).

According to a study done in Peshawar the incidence of common ENT diseases presenting in OPD are chronic tonsillitis $37 \%$, CSOM 14\%, rhinitis due to deviated nasal septum $67 \%$.

A study done on prevalence of allergic rhinitis in Oman showed that $7 \%$ patients with nasal symptoms attended the ENT OPD (18). A study performed in France on allergic rhinitis and itžs affect on sleep showed that sleep impairment was significantly worse with allergic rhinitis. Everyday living is also impacted by allergic rhinitis due to lack of sleep (19). Studies showed that aeroallergens are the primary triggers for respiratory tract diseases (20).

Asthma is a worldwide common disease in children and adults (21). According to a report of WHO asthma a life threatening disease roughly effect 100 and 150 million people around the globe and over 180,000 deaths occur from this condition annually. About $8 \%$ of Swiss population suffers from asthma. There are about 3 million asthmatics in Japan and 4 million in Germany. A rough estimate in India indicates a prevalence of between $10 \%$ and $15 \%$ in 5-11 year old children (22). The prevalence of asthma in Pakistan is increasing day by day with an annual increase of $5 \%$ of which $20 \%$ to $30 \%$ are children between 13 and 15 years of age. Nearly 20 mil- lion people about $12 \%$ of Pakistani adult population are suffering from disease (23).

According to a study done at Military Hospital Attockotomycosis (a fungal ear infection common in tropical countries) is a common condition often seen in ENT OPD and in this study its prevalence is about 7\% among patients who presented with sign and symptoms of otitis media. Its various predisposing factors are humid climate, presence cerumen, instrumentation of ear and increase use of antibiotics (24). Otitis media with effusion is also a common medical in Indian children and its prevalence has been quoted $16.6 \%$ in children of age 5 to 7 (25). According to a report of WHO 5\% of world population 360 million people has disabling hearing loss (a person who is not able to hear as well as someone with normal hearing _hearing threshold of 20 decibel or below in both ears is to have hearing loss) (26).

A study done on symptoms of ENT diseases showed that headache was the main symptom in patients presented in ENT OPD (27).

A study done on ear ,nose and throat diseases showed that common ear, nose and throat disorders were seen in patients aged $<15$ years are otitis media, obstructive adenoids and foreign bodies in the ear whereas hearing loss, rhino sinusitis and tumours were the common disorder of ENT in patient aged 16 years and above (28).

Chronic rhino sinusitis (CRS) a clinical syndrome characterized by mucosal infection of nose and paranasal sinuses is one of the most prevalent chronic diseases worldwide. It is the second most chronic condition in United States, affecting one in seven American adults (29). In USA prevalence of sinusitis is estimated to be $14 \%$ of global population. Patients with particular disease more often develop sinusitis such as $25-30 \%$ of allergic patients, $43 \%$ of asthmatic patients, $37 \%$ of patients with transplants and $54-68 \%$ of patients with AIDS (30). Studies from tertiary care centres indicate a high prevalence of fungal rhino sinusitis in India. This was found in $70 \%$ young males in 10-39 years age group from rural India (31).

\section{MATERIAL AND METHODS}

This was a cross sectional descriptive type of study at Ayub Teaching Hospital Abbottabad. The study was done over a period from December 2015 to June 2016. The sample size was 250. Non Probability convenient sampling. Patients with different ENT diseases presenting at ENT OPD of Ayub Teaching hospital Abbottabad were included. All patients who are in emergency condition were excluded. Data was collected using a structural questionnaire after pretesting. The data after collection was entered and analyzed using statistical software SPSS-16. Mean and standard deviation were calculated 
for quantitative variables like age, monthly family incomes etc. while frequencies and percentages were calculated for categorical variables like gender, socioeconomic etc. Results were displayed as tables and graphs.

\section{RESULTS}

Table 1. Gender of patients

\begin{tabular}{|l|c|c|}
\hline & Frequency & Percentage (\%) \\
\hline Male & 129 & $51.6 \%$ \\
\hline Female & 121 & $48.4 \%$ \\
\hline Total & 250 & $100 \%$ \\
\hline
\end{tabular}

Table 1 shows that out of total 250 patients, 129 $(51.6 \%)$ were males and $121(48.4 \%)$ were females.

Table 2. Socioeconomic status

\begin{tabular}{|l|c|r|}
\hline & Frequency & Percent \\
\hline Poor & 165 & $66.0 \%$ \\
\hline Middle & 72 & $28.8 \%$ \\
\hline Upper & 13 & $5.2 \%$ \\
\hline Total & 250 & $100.0 \%$ \\
\hline
\end{tabular}

Table 2 shows that majority $165(66 \%)$ of patients were poor, $72(28.8 \%)$ belonged to middle class and 13 $(5.2 \%)$ were from upper class.

Occupation

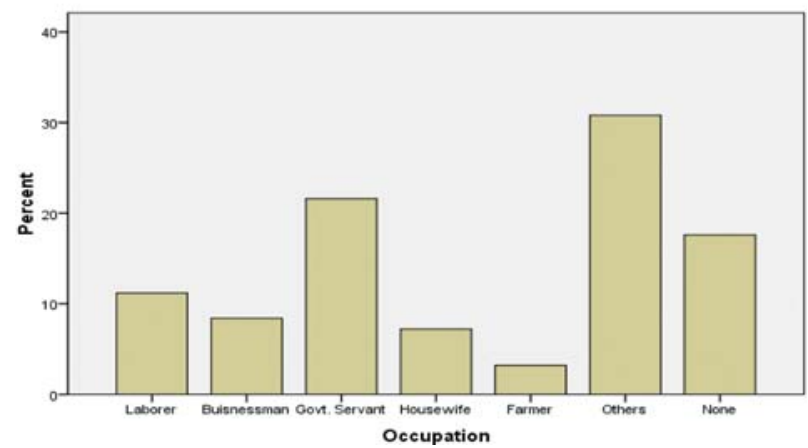

Figure 1. Occupation

Figure 1 shows that out of 250 patients, $28(11.2 \%)$ were laborer, $21(8.4 \%)$ were businessman, 54 (21.6\%) were government servant, $18(7.2 \%)$ were housewife, 8 (3.2\%) were farmers, $77(30.8 \%)$ had other jobs and 44 (17.6\%) had no jobs.

Table 3 shows that out of total 250 patients, 33 $(13.2 \%)$ were suffering from acute otitis media, 21 (8.4\%) had acute pharyngitis, $11(4.4 \%)$ had acute sinusitis, $13(5.2 \%)$ had acute tonsillitis, $33(13.2 \%)$ had allergic rhinitis, $38(15.2 \%)$ had bilateral ear wax, 10 (4.0\%) had chronic pharyngitis, $27(10.8 \%)$ had chronic supporative otitis media, $26(10.4 \%)$ had chronic tonsillitis, 20 $(8.0 \%)$ had deviated nasal septum, $7(2.8 \%)$ had epistaxis and $11(4.4 \%)$ were suffering from otitis externa.
Table 3. Diagnosis

\begin{tabular}{|l|r|r|}
\hline & Frequency & Percent \\
\hline Acute otitis media & 33 & $13.2 \%$ \\
\hline Acute pharyngitis & 21 & $8.4 \%$ \\
\hline Acute sinusitis & 11 & $4.4 \%$ \\
\hline Acute tonsillitis & 13 & $5.2 \%$ \\
\hline Allergic rhinitis & 33 & $13.2 \%$ \\
\hline Bilateral ear wax & 38 & $15.2 \%$ \\
\hline Chronic pharyngitis & 10 & $4.0 \%$ \\
\hline Chronic supporative otitis media & 27 & $10.8 \%$ \\
\hline Chronic tonsillitis & 26 & $10.4 \%$ \\
\hline Deviated nasal septum & 20 & $8.0 \%$ \\
\hline Epistaxis & 7 & $2.8 \%$ \\
\hline Otitis externa & 11 & $4.4 \%$ \\
\hline Total & 250 & $100.0 \%$ \\
\hline
\end{tabular}

Duration of illness

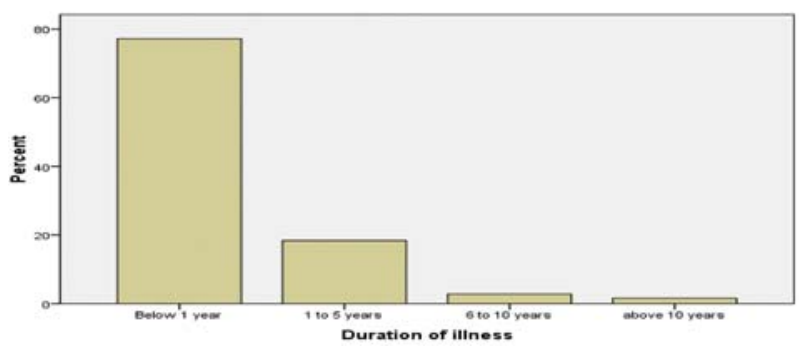

Figure 2. Duration of illness

Figure 2 shows that out of total 250 patients, 193 (77.2\%) patients had duration of illness below 1 year, $46(18.4 \%)$ had 1 to 5 years, $7(2.8 \%)$ had 6 to 10 years and $4(1.6 \%)$ had above 10 years duration of illness.

Table 4. Nature of visit

\begin{tabular}{|l|c|c|}
\hline Nature of visit & Frequency & Percent \\
\hline First & 117 & 46.8 \\
\hline Follow up & 133 & 53.2 \\
\hline Total & 250 & 100.0 \\
\hline
\end{tabular}

Table 4 shows that out of total 250 patients, 117 (46.8\%) patients had first visit to hospital and 133 $(53.2 \%)$ patients were follow up.

Any treatment taken before

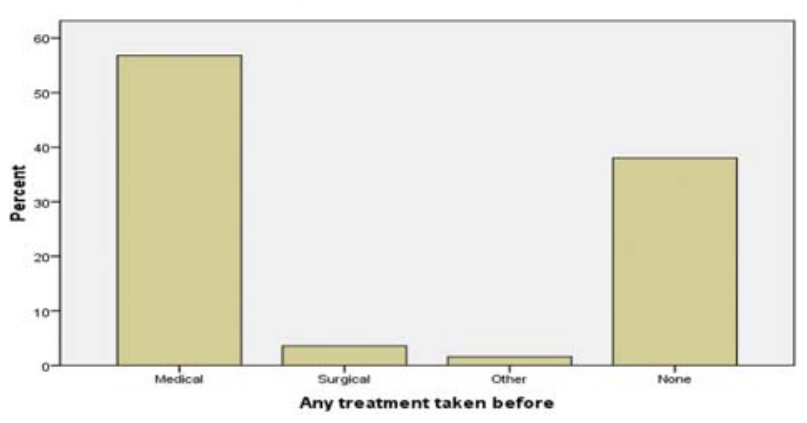

Figure 3. Any treatment taken before 
Figure 3 shows that out of total 250 patients, 142 (56.8\%) had taken medical treatment, $9(3.6 \%)$ had taken surgical treatment, $4(1.6 \%)$ had taken other treatment and $95(38.0 \%)$ had taken no treatment before.

\section{DISCUSSION}

The pattern of ENT disease is quiet variable depending on age \& group varying from community to community. A prospective cross sectional study of all consecutive patients coming to otolaryngology clinic in Oman was done on allergic Rhinitis and associated co morbidities. In this study allergic Rhinitis was noted in $48 \%$ of patients. According to our study out of 250 cases 33 patients $(13.2 \%)$ were of allergic rhinitis. The difference in result is due to sample size which is small in our study (18).

A study done in India on the Prevalence of preventable ear disorders in primary school children (aged 5 to 12 years) through pro-forma questionnaire in 15718 primary school children. Most common ENT disorders seen in these children were Ear wax in $7.93 \%$, chronic otitis media in $4.79 \% \& 3.66 \%$ suffered from otitis media with effusion. Acute otitis media was detected in $0.65 \%$ children and foreign bodies were found in $0.34 \%$. According to our study, out of 250 patients of bilateral ear wax are $(15.2 \%$, chronic otitis media $10.8 \%$ and acute otitis media $13.2 \%$. Difference in results is due to sample size and age groups (32).

In our study patient occupational classes showed that there were more patients in lower occupational classes than in those in upper classes. Same results are showed by a study done in England by SL Isaac et al (33). A prospective study carried out at ENT department of KMC Peshawar Pakistan from April 2011 to May 2012 a total of 32800 patients showed the distribution of diseases systemically that is ear diseases were $47 \%$, 36\% Nasal complaints and 17\% Laryngopharyngeal. In our study ear diseases are $43.6 \%$. Nasal complaints are $28 \%$ and $28.4 \%$ complaints are of Laryngopharyngeal problems. The difference in frequency distribution is due to large size (4).

A prospective study was conducted at tertiary care hospital in Peshawar Pakistan. Most of the ENT disorders were diagnosed in those infants were Pharyngitis (30\%) Otitis media $29.33 \%$, tonsillitis $(25.33 \%)$ and Nasal Obstruction (5.3\%.) This study shows that ENT, diseases are more common in children (34). In our study cases of tonsillitis are 16\%, Pharyngitis $12.4 \%$ and otitis media $24 \%$. Results are different because of difference in age group.
A study done in Nepal on prevalence of ENT diseases in children shows that low socioeconomic status, overcrowding $\&$ joint families might be responsible for the high prevalence of ENT diseases (35).

\section{CONCLUSION}

From this study, frequency of ENT diseases among patients presenting at ENT OPD at Ayub Teaching Hospital Abbottabad, we concluded that $15.2 \%$ patients had bilateral ear wax, $13.2 \%$ had allergic rhinitis and acute otitis media, $10.8 \%$ had chronic suppurative otitis media, $10.4 \%$ had chronic tonsillitis, $8.4 \%$ had acute pharyngitis, $8 \%$ had deviated nasal septum, $5.2 \%$ had acute tonsillitis, $4.4 \%$ had acute sinusitis and otitis externa, $4 \%$ chronic pharyngitis and $2.8 \%$ had epistaxis. The main determinant is that ENT diseases are more in males and lower socio-economic families because of poor nutrition, poor housing and poor hygiene.

This study shows that allergic rhinitis, bilateral ear wax acute and chronic suppurative otitis media and pharyngitis are the common ear, nose and throat disorders.

\author{
Abbreviations \\ ENT - Ear, Nose and Throat (Otorhinola- \\ ryngology) \\ OPD - Outpatient department \\ SPSS - Statistical Package for the Social Sci- \\ WHO - World health organization \\ CSOM - chronic supprative otitis media \\ TL - Total laryngectomy \\ ND - Neck dissection \\ RA - Radiotherapy alone \\ CRS - Chronic rhino sinusitis \\ USA - United States of America \\ AIDS - Acquired immunodeficiency syndrome
} ences

\section{Conflict of Interest}

No author has any potential conflict of interest.

\section{Financial Disclosure}

The work received no external financial support.

\section{Licensing}

This work is licensed under a Creative Commons Attribution 4.0 International (CC BY 4.0) License. 


\title{
Sažetak
}

\section{UČESTALOST OBOLJENJA KOD PACIJENATA PREGLEDANIH U ORL AMBULANTI U AJUB UNIVERZITETSKOJ BOLNICI ABBOTTABAD}

\author{
Qayyum Fahad Shah, ${ }^{1}$ Fayyaz Salma ${ }^{2}$ \\ ${ }^{1}$ Ayub Medical College, Abbottabad, Pakistan \\ ${ }^{2}$ Al-Muslim Public School Battagram, Mansehra, Pakistan
}

Uvod: Pacijent se ambulantno javlja specijalisti otorinolaringologije zbog poremećaja uva, grla i nosa. Oboljenja koja zahvatuju regiju uha, grla i nosa su ozbiljni javno zdravstveni problem prvenstveno zbog njihove univerzalne distribucije morbiditeta, koja zahvata region glave i vrata. Ciljevi naše studije bili su da se uoči frekventnost ORL bolesti kod pacijeata, koji se javljaju specijalisti otorinolaringologije u Ajub Univerzitetskoj Bolnici Abotabad.

Metod: Ova studija izvedena je u Ajub Univerzitetskoj Bolnici Abotabad u periodu od decembra 2015. do avgusta 2016. godine. Pacijenti koji su se javili specijalisti otorinolaringologije u Ajub Univerzitetskoj bolnici Abotabad bili su uključeni u studiju. Podaci vezani za ORL simptomatologiju, kao i ostale informacije od značaja, bili su sakupljani kroz dobro strukturisan upitnik. Podaci nakon sakupljanja su kompjuterski uneti i obrađivani koristeći SPSS-16.

\section{REFERENCES}

1. MedicineNet. Definition of ENT [online].[cited on 2016 Jan 25] Available from URL: http://www.medicinenet.com/ script $/$ main/art.asp?articlekey $=3252$

2. Fasunla AJ, Samdi M, Nwaorgu OG. An audit of Ear, Nose and Throat diseases in a tertiary health institution in South-western Nigeria. Pan Afr Med J. 2013; 14(1) 6-12.

3. Seth Scott Bishop Diseases of the Ear, Nose, and Throat and Their Accessory Cavities: A Condensed Text-Book. FA Davis Company, 1897.

4. Khan AR, Khan SA, Arif AU, Waheed R. Analysis of ENT diseases at Khyber teaching hospital, Peshawar. J Med Sci. 2013; 21(1): 7-9.

5. World health organization. Chronic suppurative otitis media [online]. [cited on 2016 Feb 10] Available from URL: http: //www. who.int/pbd/publications/ Chronic suppurative otitis_media.pdf.

6. Finnbogadottir AF, Petersen H, Laxdal T, Gudbrandsson F, Gudnason T, Haraldsson A Mastoiditis in children in Iceland Laeknabladid. 2007; 93 (4): 275-80.

7. PL Dhingra, Shruti Dhingra, Textbook of diseases of Ear, Nose and Throat and Head and Neck surgery. 6th ed. Elsevier publisher; 2014.

8. Fatakia A, Winters R, Amedee RG. Epistaxis: a common problem. Ochsner J. 2010; 10(3): 176-8.

9. Guarisco JL, Graham 3rd HD. Epistaxis in children: causes, diagnosis, and treatment. Ear, nose, throat J. 1989; 68(7): 522-8
Rezultati: Najmlađi pacijent je imao 1 godinu, a najstariji 80 godina. Od ukupno 250 pacijenata, 129 $(51,6 \%)$ su bili muškarci, a $121(48,4 \%)$ žene. Štaviše većinu pacijenata, $181(72,4 \%)$ činili su stanovnici Abotabada i većina njih je bila niskog materijalnog stanja i to 165 (66,5\%). Najčešći broj pacijenata je imao obostrano zapušenje spoljašnjeg ušnog kanala, zbog povećane ušne masti $(15,2 \%)$, na drugom mestu su pacijenti sa akutnim zapaljenjem srednjeg uha $(13,2 \%)$ $\mathrm{i}$ oni sa alergijskim rinitisom, koji je imalo $13,2 \%$ ispitanika.

Zaključak: Može se zaključiti iz naše studije da je najčešći problem ORL patologije obostrano zapušenje spoljašnjeg ušnog kanala ušnom masti, alergijski rinitis, akutni otitits media, hronični supurativni otitis media i devijacija nosne pregrade. Najčešći uzrok su infekcije, slaba higijena i smanjena uhranjenost.

Ključne reči: učestalost, ORL bolesti, otitis media.

10. Kucik CJ, Clenney T. Management of epistaxis. Am Fam Physician. 2005; 71(2): 305-11.

11. Mackenzie M. A manual of diseases of the throat and nose, including the pharynx, larynx, trachea, oesophagus, nose and, and nasopharynx. 1st ed. Willian wood and comp, New York. 1880.

12. Gong H, Shi Y, Zhou X, Wu C, Cao P, Xu C et al. Microbiota in the throat and risk factors for laryngeal carcinoma. Appl Environ Microbiol. 2014; 80(23): 7356-63.

13. Heroiu Cataloiu AD, Danciu CE, Popescu CR. Multiple cancers of the head and neck. MFdica. 2013; 8(1): 80-5.

14. Shaikh KR. Topographic distribution of laryngeal cancer. J Liaquat Uni Med Health Sci. 2007; 6(3): 124-6.

15. Hamid A, Sattar F, Din S. Prevalence rate and morbidity pattern of common ENT diseases and disorders in infants and children. Journal of Postgraduate Medical Institute (Peshawar-Pakistan). 1991; 5(2): 59-67.

16. Saha S, Chandra S, Mondal PK, Das S, Mishra S, Rashid MA et al. Emergency otorhinolaryngolocal cases in Medical College, Kolkata - a statistical analysis. Indian J Otolaryngol Head Neck Surg. 2005; 57(3): 219-25.

17. Gaur K, Kasliwal N, Gupta R. Association of smoking or tobacco use with ear diseases among men: a retrospective study. Tob Induc Dis. 2012; 10(1):4.

18. Al-Abri R, Bharghava D, Kurien M, Chaly V, Al-Badaai Y, Bharghava K. Allergic rhinitis and associated comorbidities: prevalence in oman with knowledge gaps in literature. Oman Med J. 2014; 29(6): 414-8.

19. Pillai A. Patients with severe allergic rhinitis are more often affected by sleep disorders. Thorax. 2007; 62(2): 130. 
20. Ahmad F, Yousaf F, Asif S. Prevalence of allergic disease and related allergens in Pakistan in 2007. Journal of Postgraduate Medical Institute (Peshawar-Pakistan). 2011 21; 25(1): $14-23$.

21. Adobamen PR, Egbagbe EE. Prevalence of Throat Symptoms in Asthmatic Patients in Nigeria. Pakistan Journal of Otolaryngology. 2013; 29:47-8.

22. World Health Organization. Bronchial Asthma. [online]. [cited on 2016 March 14]. Available from URL: http:// www.who.int/mediacentre/factsheets/fs206/en/.

23. Chiesi Pakistan.Respiratory diseases [Šonline]. [cited on 2016 April 12]. Available from URL: http://www.chiesipakistan.com/index.php?page=Respiratory+Diseases.

24. Anwar K, Gohar MS. Otomycosis; clinical features, predisposing factors and treatment implications. Pak J Med Sci. 2014; 30(3): 564-7.

25 Sanli A, Tasdemir O, Eken M, Celebi O, Yilmaz SH. Prevalence of otitis media with effusion among primary school age-children and etiopathogenic examination. Indian Journal of Otolaryngology and Head \& Neck Surgery. 2014; 66(1): 95-8.

26. World health organization. Prevalence of hearing loss [online]. [cited on 2016 April 13]. Avalible from URL: http:// www.who.int/pbd/deafness/WHO_GE_HL.pdf.

27. Reck R. Headaches caused by ENT diseases. Radiologe. $1984 ; 24(8)$ : 376-80

\section{Correspondence to/Autor za korespondenciju}

Dr. Shah Fahad Qayyum

Gohar Sons, Peeple Chowk

Nowshera cantt.

Pakistan

tel: 00923439149039

email: sfask2013@gmail.com
28. Fasunla AJ, Samdi M, Nwaorgu OG. An audit of Ear, Nose and Throat diseases in a tertiary health institution in South-western Nigeria. Pan Afr Med J. 2013; 14:1.

29. Chaaban MR, Walsh EM, Woodworth BA. Epidemiology and differential diagnosis of nasal polyps.Am J Rhinol Allergy. 2013; 27(6): 473-8.

30. Van Cauwenberge P, Watelet J. Epidemiology of chronic rhinosinusitis. Thorax. 2000; 55(Suppl 2): S20-1.

31. Chakrabarti A, Rudramurthy SM, Panda N, Das A, Singh A. Epidemiology of chronic fungal rhinosinusitis in rural India. Mycoses. 2015; 58(5): 294-302.

32. Chadha SK, Sayal A, Malhotra V, Agarwal AK. Prevalence of preventable ear disorders in over 15000 schoolchildren in northern India. The Journal of Laryngology \& Otology. 2013; 127(01): 28-32.

33. Isaacs SL, Schroeder SA. Class - the ignored determinant of the nation's health. N Eng J Med. 2004 ;351(11): 1137-42.

34. Hamid A, Sattar F. Prevalence rate and morbidity pattern of common ENT diseases and disorders in infants and children. Journal of Postgraduate Medical Institute (Peshawar-Pakistan). 2011; 5(2): 59-67.

35. Nepali R, Sigdel B. Prevalence of ent diseases in children: Hospital based study. The internet journal of otorhinolaryngology. 2012; 14(2): 1-5. 